\title{
ВСЕСВІТНЯ ІСТОРІЯ
}

УДК 94(470+571.54.62)«17/19»

https://doi.org/10.34142/2313-2345.2019.56.06

Трубчанінов М. А.

кандидат історичних наук, доцент кафедри всесвітньої історіі Харківського національного педагогічного університету імені Г. С. Сковороди http://orcid.org/0000-0001-8432-478X

\section{СТАНОВЛЕННЯ ТА РОЗВИТОК \\ У СЕЛЯНСЬКИХ ГОСПОДАРСТВАХ ЄВРОПЕЙСЬКОЇ РОСІЇ МАСЛОРОБНОГО ПІДСОБНОГО ТОВАРНОГО ВИРОБНИЦТВА В КІНЦІ ХVIII - НА ПОЧАТКУ ХХ СТОЛІТТЯ}

У статті досліджується прочес становлення та розвитку в селянських господарствах Свропейської частини Росії підсобного товарного маслоробства протягом кіния ХVIII - початку XX ст.: географія, масштаби та динаміка, технічна еволюція та сочіально-економічна організація товарного, основні напрями розвитку селянських підсобно-промислових кластерів Свропейської Росї, щцо спеціалізувалися на виробнищтві різних видів масла. Організація малих підприємств з молокопереробки в багатьох селянських господарствах Свропейської Росії сприяла подальшому розвиткові продуктивних сил села, підвищенню його економічного потенціалу, в також поліпшенню житлових, комунально-побутових і соціально-культурних умов життя селянського населення. Автором зроблена спроба здійснити новий підхід до вивчення обраної проблеми, запропоновано власний варіант розуміння місия і ролі селянського маслоробства в розвитку окремих російських регіонів, виділити суттєві риси розвитку селянського маслоробства Свропейської Росії, найбільш важливі з точки зору врахування можливостей їх використання на користь сучасних фермерських господарств.

Ключові слова: селянське господарство, селянські підсобні виробничтва, селянське маслоробство, молокопереробка, селянське промислове підприємництво, селянин-маслороб, промислові селяни.

The article examines the process of formation and development in the farms of the European part of Russia aux iliary commodity butter production during the end of XVII - beginning of XX century. Analysis of current research on the history of development in peasant farms in European Russia during the late XVIIearly XX centuries. Ancillary butter production shows that this problem remains one of the little-studied pages in the world history of peasant industrial enterprise.

The article analyzes the geography, scale and dynamics of the development of peasant oilseed production. The main attention is paid to the study of the main factors of emergence on the scale of development of dairy farming in the peasant farms of the Vologda province. Much attention is paid to the study of the development of technical evolution and socio-economic organization of commodity oil production in peasant farms during the late XVII - early XX centuries. The article explores the main directions of development of peasant secondary industrial clusters of European Russia, specializing in the production of different types of oil. The organization of small dairy enterprises in many peasant farms in European Russia helped to further develop the productive forces of the village, increase its economic potential, and also to improve the living, communal and social and cultural conditions of life of the peasant population. The author attempts to take a new approach to the study of the selected problem, proposes his own version of understanding the place and role of peasant oil production in the development of individual Russian regions, to highlight the essential features of the development of peasant oil production in European Russia, the most important in terms of taking into account the possibilities of their use for the benefit of modern farms.

Keywords: peasant economy, peasant auxiliary production, peasant oil-growing, dairy processing, peasant industrial enterprise, peasant-oil-maker, industrial peasants.

Постановка проблеми дослідження визначається тим, що протягом кінця XVIII - початку XX ст. в соціально-економічній модернізації Російської імперії досить важливу роль відігравали різноманітні селянські підсобні промислові виробництва та промисли, якими селяни часто займалися поряд із землеробством i тваринництвом. Серед них особливе місце займала велика група селянських харчових підсобних промислових виробництв, в тому числі молокопереробні виробництва - сироваріння й 
маслоробство, які набули поширення в багатьох селянських господарствах Європейської Росії. У досліджуваний період Росія залишалася суто сільськогосподарською країною, де панівна роль належала зерновому господарству. Проте на другому місці стояв дохід селян від заняття молочним господарством. Великий прибуток давали селянським господарствам такі підсобні виробництва, як маслоробство й сироваріння. Так, на початку XX ст. лише експорт масла давав Російській імперії щорічно більше прибутку, чим вся iї золотопромисловість. Росія посідала провідне місце на світовому ринку молочних продуктів, на іiі частку припадала приблизно чверть світового експорту масла. У 1911-1912 pp. з європейської частини Росії на експорт йшло в основному «паризьке» масло 3 Вологодської губернії (30-40 \% загального російського експорту), а з Сибіру - переважно кисловершкове масло (60-70 \% загального експорту). Лише в 1913 р. Росія вивезла 80 млн кг масла. При цьому селянське масло з Вологодської губернії дедалі більше стало йти на внутрішній ринок, і до 1913 р. майже 75 \% його споживалося в Росії [Калантар 1897: 571-579].

Розвиток у селянських господарствах підсобних маслоробних і сироварних виробництв значно сприяв створенню дієвих систем підвищення ефективності регіональної економіки, коли селянське промислове підприємництво фінансувало аграрне виробництво, а останнє надавало йому просторову базу для розміщення, сировину i робочу силу. Така система взаємодії забезпечувала економічно ефективне використання в селянських господарствах наявного молочного поголів'я, давала можливість здійснення розширеного відтворення ресурсів тваринництва, значною мірою підвищувала потенціал розвитку регіону й ступінь використання загальної сукупності природно-ресурсних факторів місцевого характеру.

Аналіз актуальних досліджень 3 icторії розвитку в селянських господарствах Європейської Росії протягом кінця XVIII початку XX ст. підсобних маслоробних виробництв свідчить, що серед робіт, присвячених окремим аспектам проблеми, варто особливо відзначити монографії та наукові статті Арсеньева [Арсеньев 1879: 156], Р. А. Бертиньева [Бертынь 1931: 127], Б. Богданова i В. Боровського [Богданов 1912: 182], П. М. Вишнякова [Вишняков 1961: 94], Р. Золотницькой [Золотницкая 1992: 58-62], А. А. Калантара [Калантар 1897: 571-579] та інших. Після критичного аналізу цих наукових праць авторові вдалося виявити ті питання, які поки що не вирішені. Серед цих питань потребує особливого вивчення географія та динаміка товарного виробництва масла в селянських господарствах Європейської Росії, загальноросійські закономірності та регіональні особливості цього процесу.

Метою статті $\epsilon$ аналіз процесу розвитку в селянських господарствах Європейської Росії протягом кінця XVIII - початку $\mathrm{XX}$ ст. підсобного маслоробного виробництва, адже питання з історії малого та середнього підприємництва $є$ важливим для сучасної історичної науки. У даній статті висувається завдання комплексно дослідити основні фактори становлення й історію розвитку селянських малих молокопереробних підприємств, з'ясувати їх географію, масштаби та динаміку, проаналізувати їх технічну еволюцію, визначити їхнє місце в соціально-економічному й культурному розвиткові Росії в дорадянський період.

Наукова новизна полягає в тому, що це, можливо, одна з перших спроб комплексного дослідження становлення та розвитку селянських підсобних маслоробних виробництв Європейської Росії протягом кінця XVIII - початку XX ст. У роботі проаналізовані основні фактори створення кустарного виробництва масла в селянських господарствах Європейської Росії; проаналізовано вплив селянського підприємництва на розвиток окремих російських регіонів; визначено роль i місце селянмаслоробів у соціально-економічних і культурних здобутках Російської імперії у другій половині XIX - на початку XX ст.; зроблено внесок у справу відродження та популяризації забутих імен видатних маслоробів, які були представниками промислового селянства. До новизни роботи також цілком можна віднести широке використання в ній і включення в науковий обіг ці- 
лої групи маловідомих раніше конкретнофактичних матеріалів.

Виклад основного матеріалу. Протягом кінця XVIII - початку XX ст. Росія залишалася суто сільськогосподарською країною, де панівна роль належала зерновому господарству. На другому місці стояв дохід селян від заняття молочним господарством, зокрема, в 1910 р. дохід від нього становив 12,7 \% усієї вартості виробництва держави. Особливо великий дохід приносили селянським господарствам такі підсобні молокопереробні виробництва, як маслоробство й сироваріння [Шелков 1914: 235-240]. Селянські господарства Європейської Росії, які відрізнялися від інших сфер матеріального виробництва низкою специфічних особливостей, найбільш успішно розвивалися лише при раціональному поєднанні основних сільськогосподарських виробництв і допоміжних, підсобних промислових виробництв. Доцільність поєднання в багатьох селянських господарствах Європейської Росії сільськогосподарського виробництва 3 різними видами промислової діяльності, зокрема $з$ маслоробством і сироварінням, була зумовлена дією багатьох природних, соціально-економічних, організаційних, технологічних й інших факторів, які існували об'єктивно, взаємодіяли між собою, впливали один на одного і на результати господарювання селян у цілому.

Довгий час соціально-економічні умови кріпосницької Росії затримували розвиток у селянських господарствах товарної переробки молока. Кріпосництво, натуральне замкнуте сільське господарство, бездоріжжя, нечисленність міського населення, далекість від споживчих ринків гальмували розвиток молочного господарства і формування в селах Свропейської Росії промислового маслоробства. У цей час у селах Європейської Росії молоко та продукти його переробки використовувалися селянами переважно у своєму власному господарстві, тому що ані в цільному вигляді, ані в переробленому (сметана, сир) молоко майже не мало збуту. Продаж молочних продуктів, що накопичувались у селян, була явищем випадковим і неорганізованим. Лише селяни приміських сіл мали можли- вість продавати молоко і молочні продукти мешканцям міст [Арсеньев 1879: 123].

У селах Свропейської Росії маслоробство й сироваріння стало зароджуватися наприкінці XVIII ст. Найбільшого поширення ці селянські промисли набули в північних нечорноземних губерніях Свропейської Росії, головним чином у Тверській, Вологодській, Ярославській, Смоленській, Володимирській. Характер розвитку в селянських господарствах губерній молокопереробних промислів визначали темп й особливості становлення ринкових відносин у Росії в цілому. У багатьох як поміщицьких, так і селянських господарствах молоко стало перероблятися на пряжене, так зване «російське» масло, яке могло досить добре й довго зберігатися. Так, при кімнатній температурі воно зберігалося близько 9ти місяців, а в льодовику - до 15-ти місяців [Золотницкая 1992: 58-62].

Це був уже товарний продукт, який селяни виготовляли доволі простим способом. Молоко у глиняних глечиках видержувалось у прохолодному приміщенні близько 2-3 діб, відтак воно скисало, а на поверхні залишався шар вершків або сметани, який знімали з поверхні та вживали в їжу. Надлишки молока тривалий час накопичували в дерев'яних бочках або цебрах, а потім, часто із зіпсованої, згірклої чи протухлої сметани, в дійницях, у примітивних толкачних маслоробках-діжках збивали масло за допомогою колотівки із хвойного дерева, віджимали й топили. Із 10 л молока селяни звичайно одержували не більше 250 мг «російського» пряженого масла [Пахомов1900: 233-237]. На місцевих ринках пуд такого масла коштував 4-6 крб. Ціна на пряжене масло була значно нижчою, ніж на вершкове, а молока на нього витрачалося в півтора рази більше. Тому виробництво пряженого масла для селянства часто було малорентабельним, а прибуток від корови нерідко був удвічі меншим за витрати на їі утримання [Богданов 1912: 125-126].

Виготовлене в селянських господарствах Європейської Росії «російське» пряжене масло споживалося, головним чином, на внутрішньому ринку. Заможні селяни, власники великих маслоробок, продавали свій молочний продукт на місцевих базарах 
й ярмарках великих міст, а залишки пряженого масла селяни збували скупникам. Але місткість внутрішньому ринку була дуже низкою, тому значна частина виготовленого селянами пряженого масла в північних губерніях Європейської Росії концентрувалася на Нижегородському ярмарку, а потім через південні порти вивозилася купцями в Туреччину, Єгипет та на Балканський півострів, тобто на менш вимогливий ринок [Бертынь 1931: 89-90]. Лише в Туреччину щорічно вивозилося 24 тис. пудів пряженого масла. У 1846-1850 р. було вивезено всього 28-38 тис. пудів масла, у тому числі близько 80 \% у Туреччину. У 1851-1860 p. 3 Росії було вивезено 30-159 тис. пудів пряженого масла, у тому числі майже 70 \% в Туреччину. Відносно мало експортували селянське пряжене масло в Англію, Німеччину, Францію, Данію, Австрію та Італію, де існував досить вимогливий ринок [Шелков 1914: 235-240].

Приблизно до середини XIX ст. великі міста Росії забезпечувалися переважно емментальським сиром, який у той час вважався королем сирів і був дуже популярним у Європі. Емментальский сир, що його в Росії частіше називали швейцарським, а також вершкове масло завозилися в Росію із західноєвропейських країн, Фінляндії і Прибалтики. Ці молочні продукти вважалися ласощами й були доступні тільки для заможної частини російського населення. При цьому до 1859 р. в Російській імперії фактично діяв заборонний тариф на ввезення вершкового масла: мито за пуд становило 5 крб. 80 коп. при ціні на внутрішньому ринку 5-6 крб. за пуд. 31852 по 1859 р. включно ввезення вершкового масла становило 36413 пуд., проте у 1860 р. воно за один рік зросло на 16797 пуд., хоча в 1859 р. становило усього лише 3235 пудів [Вишняков 1961: 81-82].

У першій третині XIX ст. в Російській імперії, хоча й повільно, але відбувався розвиток промислової революції, збільшувалося міське населення, а разом із тим і зростання цін на сільськогосподарські продукти. Через це в селянських господарствах Європейської Росії намітився новий етап розвитку молочного господарства й організації промислової переробки молока на вершкове масло. Уже в 30-х роках XIX ст. в північних губерніях Європейської Роciї з'явилися перші селянські підсобні підприємства $з$ виробництва вершкового масла. До середини XIX ст. розвиток молочного господарства й початок промислової переробки молока на вершкове масло спостерігався в багатьох селянських господарствах Вологодської, Ярославської, Тверської та Смоленської губерній. У селах цих та інших губерній відбувся перехід від виробництва пряженого масла до високоякісного вершкового, економічно вигідного за витратами на сировину й скороченим циклом виробництва. Якщо на 1 пуд пряженого масла за його вартості 4-6 крб. селянимаслороби витрачали 31 пуд молока, то на 1 пуд вершкового масла вартістю 12 крб. вони витрачали 23-24 пуди молока. Виробничі витрати на вироблення 1 пуда вершкового масла були менше, ніж на виробництво пряженого, і становили 2 крб. 2 коп. При вартості на той час одного пуда молока у 40-50 коп. виробництво одного пуда вершкового масла в середньому приносило селянському господарству економічний прибуток приблизно в 10 крб. [Риффесталь 1900: 58-60].

Протягом другої половини XIX ст. початку XX ст. основні центри селянського вершкового маслоробства знаходилися у Вологодській і Ярославській губ. Особливу увагу звертала на себе якість вершкового масла, яке виготовлялося в селянських господарствах Вологодської губернії. Тут маслоробство існувало здавна, завдяки специфічним особливостям місцевого сільського господарства та сприятливим природноісторичним умовам. Унаслідок короткого літа, різких коливань температури (особливо навесні й восени), наявності підзолистих грунтів зернове господарство не мало тут умов для розвитку і не виправдувало себе. Воно розвивалося тільки на півдні губернії й не забезпечувало іiі потреб. Селянам більш вигідно було займатися тваринництвом, особливо молочного напрямку, тому вони й засновували у своїх господарствах підсобні промисли 3 переробки молока. Саме завдяки цим та іншим факторам вологодське маслоробство стало колискою селянського промислового маслоробства Єв- 
ропейської Росії. Виготовлене в селянських господарствах Вологодської губ. вершкове масло відзначалося яскраво вираженим смаком та присмаком смажених горіхів. Ці смакові переваги були підставою виділити його в особливий вид вершкового масла й називати «паризьким». Воно користувалося заслуженою славою і високо цінувалося як російськими, так й закордонними споживачами [Риффесталь 1900: 58-60].

Незабаром після свого виникнення у вологодських селах селянське маслоробство стало товарним. Уже 1879 р. у Вологодській губ. працював 51 маслоробний завод, 3 них 32 розташовувалися в поміщицьких садибах, а 19 - у селянських господарствах. На цих селянських маслоробних заводах за рік було вироблено 3975 пуд. масла на суму 118 тис. крб. [Пахомов1912: 23-29]. Селяни-маслороби випускали значну кількість високоякісного, зі специфічним смаком й ароматом, масла для постачання до Москви i С.-Петербургу, а також на експорт. У Свропі вологодське масло швидко завоювало високу репутацію й славу. У розвитку вологодського селянського маслоробства велику роль зіграло відкриття підприємцем В. І. Бландовим за підтримкою Вільного економічного товариства складів по закупівлі у селян і збуту масла. Спочатку такий склад був відкритий у С.-Петербурзі, а потім й у Вологді. Уже в першу половину 1869 р. склад у С.-Петербурзі продав 9952 кг виробленого селянами масла [Журнал Совещания 1916: 100-106].

У Вологодському краї технологія виготовлення вершкового масла в селянських господарствах встановилася не одразу, вона складалася історично, на підставі багаторічного колективного досвіду як самих селян-маслоробів, так і вчених, які на практиці зуміли найбільш доцільно використати високі природні якості молока, одержуваного в селянських господарствах. До середини 1880-х років селянське маслоробство розвивалося повільно, техніка виробництва була примітивною. Вершки одержували методом відстоювання молока протягом 2448 год. у плоских бляшаних або дерев'яних тазах. Уздовж стін хати-маслоробні селяни встановлювали полиці для розміщення тазів, а в теплу пору року тази встановлювали в підпілля [Записка Отдела 1916: 100-106]. Одержання вершків методом відстоювання вимагало великих виробничих ємностей, було процесом тривалим, малопродуктивним і перешкоджало дотриманню санітарно-гігієнічних умов розвитку селянського маслоробства. Збивання масла проводилося в ручних маслоробках, а на великих селянських маслоробних підприємствах використовували маслоробки ємкістю до 150 л 3 кінним приводом. Обробку масляного зерна проводили рифленим валиком. Формували масло по 15-20 фунтів (6-7 кг) набиванням в обкладені пергаментом рознімні форми, а потім бруски масла укладалися в ящики [Егунов 1897: 543-616]. Масло також формували за прикладом Голштинії в барила, які обкладали пергаментом. Річна продуктивність селянських маслоробних підсобних підприємств була в середньому від 800 до 2400 кг масла за рік [Деларов 1923: 1-16].

Вологодські селяни-маслоробні виготовляли вершкове солоне і несолоне масло із сирих непастеризованих вершків, а також «паризьке» масло з пастеризованих вершків. 3 поквашених сирих вершків вони виготовляли кисловершкове масло, яке часто називали «голштинським». Але російський споживач не прийняв його, і селяни перейшли тільки на вироблення солодковершкового й «паризького» масла [Ивашкевич 1992: 219-233]. У селах Вологодської губ. найчастіше вершкове несолоне й «паризьке» масло виготовлялося на великих селянських маслоробнях, із гарними льодовиками, а солоне вершкове масло - на дрібних маслоробнях. Погані пристрої на селянських маслоробнях і недотримання санітарногігієнічних умов виробництва нерідко приводили до закисання вершків, що надавало маслу кислий смак, схожий на смак «голштинського» масла. Щоб продати таке селянське масло, купці нерідко видавали його за справжне масло із Голштинії, яке колись мало попит серед споживачів. Відтак згодом усі погані сорти солодковершкового й «паризького» масла російські споживачі стали іменувати «Голштинським» [Егунов 1897: 543-616].

Різко змінився розвиток селянського маслоробства 3 появою сепаратора. Перша 
спроба застосувати відцентрову силу для відділення вершків була зроблена ще в 1860-х роках. Наприкінці 1870-х років був винайдений сепаратор із паровим двигуном, але спочатку він був занадто громіздким. Він з'явився в Росії лише на початку 1880-х років і був непридатний для невеликих селянських маслоробень. Згодом конструкція сепараторів удосконалювалася й у 1886 р. з'явилися ручні сепаратори продуктивністю до 100 л на годину, а також дуже зручні та продуктивні в роботі кінно-приводні сепаратори [Арсеньев1939: 129-130]. Із цього часу ручні й кінно-приводні сепаратори стали швидко поширюватись у селах Європейської Росії, повністю витиснувши метод відстоювання вершків. Сепарування прискорило переробку молока на масло, покращилася якість продукту, знизилася його собівартість, утворилися передумови для розвитку мережі селянських маслоробень і підвищення їхньої продуктивності. У багатьох селах Свропейської Росії стали з'являтися селянські та всестанові артільні маслозаводи, що переробляли до 500 пудів (8000 кг) молока на день, що було фізично неможливо з методом відстоювання [Журнал Совещания 1916: 100-106]. Сепаратор відіграв вирішальну роль у технічному прогресі селянського маслоробства, без нього модернізація селянського маслоробства була неможливою.

Для розвитку селянського маслоробства у Вологодській губернії поява сепаратора й побудова таких залізниць як Вологда-Ярославль, Вологда-Архангельськ і Вологда-Петербург не лише сприяли вдосконаленню техніки виробництва масла, а й дали потужний поштовх процесу швидкого поширення маслоробного промислу серед селянського населення. Бурхливий розвиток селянського маслоробства у Вологодській губернії спричинило організацію в 1885 p. інституту пересувних маслоробень, які очолювалися фахівцями в маслоробній справі. Такі начальні маслоробні переїжджали 3 однієї селянської маслоробні до іншої, де залишалися від 2 тижнів до 3-4 місяців і демонстрували правильну технологію виробництва масла. Іноді начальні маслоробні приймали для навчання селян, які проходили курс молокопереробної справи. До кінця 1889 р. у Вологодській губернії налічувалося 254 маслозаводи. При цьому більшість із них були побудувані в селах і належали селянам-підприємцям [Отчеты артелей1912: 45-48].

До 1894 р., поки не відкрився рух по Сибірській залізниці, селянське маслоробство в Європейській Росії було зосереджене головним чином у Вологодській і Ярославській губ. Із розвитком селянського маслоробства ціни на масло на внутрішньому ринку стали знижуватися 3 одночасним підвищенням цін на молоко. Ціни на масло на зовнішньому ринку були вищими, тому збільшувався вивіз масла, яке виготовлялося в селянських промислових господарствах, за кордон. Однак із 1881 р. ціни на масло за кордоном почали сильно знижуватися, хоча вивіз масла за кордон збільшувався [Записка Отдела 1916: 100-106].

У другій половині 1880-х і початку 1890-х років ціни на молоко в Свропейській Росії досягли свого максимуму. Така розбіжність цін на сировину й на масло ускладнило розвиток селянського маслоробства, і з 1890-х років виробництво масла в селянському середовищі являло собою ряд малих маслоробень із середнім оборотом від 370 до 1400 крб. у кожній [Ивашкевич 1992: 219-230]. Значна частина селян-маслоробів знайшли вихід із дисбалансу (низьких цін на масло і високих - на молоко), що утворився на ринку, у здешевленні виробництва масла. Це відбувалося за рахунок винаймання найдешевших приміщень, де важко було дотримуватися необхідних санітарногігієнічних умов; використання дешевої некваліфікованої робочої сили; скупки молока по найнижчих цінах; використання тільки одного сепаратора, що працював цілодобово [Ивашкевич 1992: 233].

Значну частину селянських маслоробень скупили господарі молочних крамниць, де продавалися сільські продукти, вони теж стали виготовляти масло. Для вигідності виробництва вони стали платити селянам за молоко не готівкою, а низькосортним товаром, недодаючи на кожен карбованець по 25-40 коп. Відтак крамарімаслороби одержували значні прибутки навіть за низької якості масла, яке вони виробляли [Обзор состояния 1912: 71-74]. 
Коли зросла конкуренція у скупці молока, крамарі-маслороби віднайшли різні способи заставити селян продавати їм молоко за низькими цінами. Так, вони давали селянам товар у борг у рахунок майбутньої здачі ними молока; скуповували пустища й вигони для корів і здавали їх в оренду селянам; утримували у своїх господарствах биків-виробників, яких теж здавали в оренду селянам; вносили за селян заздалегідь податки тощо. Тих, хто відмовлявся продавати задешево молоко крамарям-маслоробам, позбавляли кормів, вигонів, биків для злучки. Щоб не втратити постачальників молока, вигідних покупців товару 3 молочної крамниці та надії на сплату за раніше забраний у борг товар, крамар змушений був миритися із прийомом брудного, кислого, часом розведеного водою молока.

Щороку ціни на молоко зростали, ціни на масло падали, а вимоги до його якості на ринку підвищувалися, тому крамаряммаслоробам i за найбільших прибутків у торгівлі дедалі важче стало зводити кінці 3 кінцями [Арсеньев1939: 122-29]. Відтак у Вологодській губернії виросли цілі сотні дрібних маслоробень 3 антисанітарним та некваліфікованим виробництвом масла низької якості, що, у свою чергу, призвело до падіння на нього цін. У зв'язку із цим на початку 1890-х років продаж масла ускладнювався, спостерігалося переповнення внутрішніх ринків, тим паче, що масло було недоступним для основної маси російського населення. Відтак знову почався експорт масла за кордон, особливо в сезон його виробництва - улітку й восени. Закордонний ринок вимагав тільки солоне кисловершкове масло, тому вологодські селяни-маслороби стали переходити замість виробництва солодковершкового й «паризького» масла на експортне кисловершкове [Пахомов1900: 16-19].

Розвиткові експорту селянського масла з Вологодської губернії значно сприяло відкриття у Вологді в 1892 р. першої експортної контори «Мерк-Паллизен», що займалася скупкою масла у селян-маслоробів та відправленням його за кордон, переважно у Копенгаген, Гамбург, Единбург, Гулль і Лондон [Пахомов1900: 16-19]. Окрім скупки селянського масла, ця експортна кон- тора виконувала функції постачання селянам-маслоробам необхідних припасів і матеріалів, зокрема сепараторів, букових діжок, пергаменту тощо. Ця ж контора посилала в села, де розвивалася селянська переробка молока, майстрів, які мали навчити селян виробництва масла, що відповідало кондиціям експортного.

Значну роль у розвиткові селянського маслоробства у північних районах Європейської Росії, у тому числі й Вологодській губернії, відіграло відкриття Н. В. Верещагіним у 1871 р. школи маслоробства й сироваріння в с. Сдимоново Корчевського повіту Тверської губернії.

За 27 років своєї роботи Єдимоновська школа підготувала 1200 майстрів, які відіграли велику роль у розвиткові маслоробства у Вологодській, Ярославської та інших північних губерніях Європейської Росії. До школи молочного господарства 3 усіх теренів Росії посилали учнів. Уже в 1879 р. під керівництвом М. В. Верещагіна було навчено більше 200 майстрів [Отчеты артелей1912: 45-48].

Єдимоновська школа молочного господарства була однією 3 найвідоміших у світі. Сюди приїжджали вчитися баварці, австрійці, шведи, турки та навіть швейцарці. Вона була навчальним центром селянського сироваріння й маслоробства, сюди приїжджали не лише селяни, а й земські та громадські діячі, землевласники, представники науки, підприємці - усі, хто цікавився розвитком молочногосподарського промислу в селах Європейської Росії. М.В.Верещагін, А. А. Калантар, Н. І. Бландов, Г. А. Бирюльов, А. І. Тимирьов, А. А. Попов, інші співробітники й випускники Єдимоновської школи сироваріння й маслоробства поклали початок широкому розвитку переробки молока в селянських господарствах Європейської Росії [Пахомов 1900: 233-237].

На початку XX ст. в селах Європейської Росії значного поширення набула кооперація селян-маслоробів. Вона дозволяла значно підвищити результативність товарного виробництва масла в селянських господарствах за рахунок надання різноманітних послуг: кредитування, збут продукції, постачання товарів й обладнання. Значну 
роль у розвиткові кооперації в селянському маслоробстві відіграла тарифна політика уряду, що виконувала широку функцію та формувала територіальну спеціалізацію сільського господарства на молочному тваринництві. Політика уряду також передбачала видачу позик і пільгових кредитів власникам селянських приватних і кооперативних маслоробних закладів [Пахомов 1900: 233-237].

\section{Висновки і перспективи подальших} досліджень. Таким чином, вивчений та узагальнений автором фактичний матеріал переконливо свідчать, що наприкінці XVIII на початку XIX ст. Російська імперія вступила у фазу активних модернизаційних перетворень, одним із двигунів яких виступило селянське промислове підприємництво. $\mathrm{У}$ цей час розпочався процес становлення й розвитку в селянських господарствах $\mathrm{CB}_{\text {- }}$ ропейської частини Росії підсобного товарного маслоробства. Переробка молока та виробництво масла на селянських підсобних промислових підприємствах була зумовлена дією декількох взаємозумовлених і взаємозалежних факторів. Саме тому протягом кінця XVIII - початку XX ст. селян- ське маслоробство в селах Європейської Росії розвивалося досить інтенсивно. Наявність величезної території та регіонів, що відрізнялися за своїм географічним положенню, рівнем економічного і соціального розвитку, визначили об'єктивні особливості формування й розвитку селянського товарного маслоробства. Разом із розширенням його масштабів та географії поступово розвивалася й удосконалювалася соціальноекономічна й технічна організація.

Вивчений матеріал дозволяє констатувати, що такий вид господарської діяльності селянства, як маслоробство, значно вплинув на соціально-економічний розвиток Європейської Росії. Найбільшого розвитку маслоробний селянський промисел набув у північних нечорноземних губерніях Європейської Росії, головним чином у Тверській, Вологодській, Ярославській, Смоленській, Володимирській. Характер розвитку в селянських господарствах цих губерній маслоробного й сироварного промислів визначався темпом й особливостями становлення ринкових відносин у Російській імперії в цілому.

\section{ЛІТЕРАТУРА}

Аверин А., Быстров М., Булкин М. Животноводство и маслоделие Вологодской области. Вологда, 1939. 211 c.

Арсеньев Ф. А. Молочное дело в Вологодской губернии. Вологда, $1879.156 \mathrm{c}$.

Артельное маслоделие Вологодской губернии. Вологодское общество сельского хозяйства. Вологда, 1916. $238 \mathrm{c}$.

Бертынь Р. А. Производство парижского масла. М.; Л. $1931.127 \mathrm{c}$.

Богданов Б., Боровский В. Маслодельные артели в Вологодской губернии. Вологда, 1912. 182 c.

Вишняков П.М. Вологодское масло. Вологда, 1961. 94 с.

Деларов Д. И. Северная область - иентр молочного хозяйства // Тр. ВМХИ. Вологда, 1923. С. 1-16.

Егунов М.А. Современное положение артельного маслоделия в России // Сельское хозяйство и луговодство. 1897. Т. 134. №3. СПб. С. 543-616.

Журнал Совещания о нуждах крестьянских маслодельных промыслов. СПб. 1916. 128 с.

Записка Отдела сельской экономии и сельскохозяйственной статистики по вопросу о значении и нуждах кустарной промышленности. СПб. 1905. 535 c.

Золотниикая Р. История развития маслоделия Вологодчины // Молочная промышленность. 1992. № 1. C. $58-62$.
Ивашкевич И.О. Молочное хозяйство и маслоделие // Ежегодник департамента земледелия и лесного департамента. СПб., 1908. С. 219-233.

Калантар А. А. Современное положение артельного маслоделия в России // Сельское хозяйство и лесоводство. T. 34, № 3. 1897. С. 571-579.

Обзор состояния сельского хозяйства в Вологодской губернии. Тамбов. $1912.114 \mathrm{c}$.

Отчеть артелей Вологодской губернии. Вологда, 1909. $163 \mathrm{c}$.

Пахомов П. Очерк современного состояния молочного хозяйства в России // Выставка 1900 г. Каталог молочного отдела выставки. М., 1900. 152 c.

Риффесталь К.Ф. Отчет инструктора молочного хозяйства для северных губерний. Вологда, 1903. $119 \mathrm{c}$.

Свод статистических сведений по сельскому хозяйству России к концу ХІХ века. СПб., 1903. 334 с.

Степановский И.К. Маслоделие - богатство Севера. Вологда, 1912. 149 c.

Шелков П.И. Маслодельнье артели Вологодской губернии. М., 1914. 325 c. 


\section{REFERENCES}

Averin A., Bystrov M., Bulkin M. Livestock and oilmaking in the Vologda Oblast. Vologda, 1939.

Arseniev F.A. Dairy business in the Vologda province. Vologda, 1879 [in Russian].

Artel oil making in the Vologda province. Vologda society of agriculture. Vologda, 1916 [in Russian].

Bertyn R.A. Paris oil production. M.- L., 1931 [in Russian].

Bogdanov B. \& Borovsky V. Oil-making cooperatives in the Vologda province. Vologda, 1912.

Vishnyakov P.M. Vologda oil. Vologda, 1961 [in Russian].

Delarov D.I. Northern region - the center of dairy farming // Tr. VMHI. Vologda, 1923. P. 1-16.

Egunov M.A. The current situation of artel oil making in Russia // Agriculture and meadow farming. 1897. T. 134. No. 3. SPb. 1897, P. 543-616 [in Russian].

Journal of the Meeting on the needs of peasant oil and gas crafts. SPb., 1916 [in Russian].

Note by the Division of Rural Economy and Agricultural Statistics on the importance and needs of the cottage industry. SPb., 1905 [in Russian].

Zolotnitskaya R. History of the development of oil production in the Vologda region // Dairy industry. 1992. No. 1. P. 58-62 [in Russian].
Ivashkevich I.O. Dairy farming and oil production // Yearbook of the Department of Agriculture and Forestry Department. SPb., 1908. P. 219-233 [in Russian].

Kalantar A.A. The current situation of artel oil making in Russia // Agriculture and Forestry. T. 34, No. 3. 1897. P. 571-579 [in Russian].

Overview of the state of agriculture in the Vologda province. Tambov. 1912 [in Russian].

Reports of the cooperatives of the Vologda province. Vologda, 1909 [in Russian].

Pakhomov P. Essay on the current state of dairy farming in Russia // Exhibition 1900. Catalog of the dairy department of the exhibition. M., 1900 [in Russian].

Riffestal K.F. Dairy Instructor Report for the Northern Provinces. Vologda, 1903 [in Russian].

A compilation of statistical information on agriculture in Russia by the end of the 19th century. SPb., 1903 [in Russian].

Stepanovsky I.K. Butter is the wealth of the North. Vologda, 1912 [in Russian].

Shelkov P.I. Butter cooperatives of the Vologda province. M., 1914 [in Russian]. 